\title{
A Georgist Perspective of Petroleum Taxation
}

Joseph Leeson

Indiana University Maurer School of Law, jleeson@indiana.edu

Follow this and additional works at: https://www.repository.law.indiana.edu/ijgls

Part of the Comparative and Foreign Law Commons, Natural Resources Law Commons, Oil, Gas, and Mineral Law Commons, Property Law and Real Estate Commons, Taxation-Federal Estate and Gift Commons, Taxation-State and Local Commons, and the Tax Law Commons

\section{Recommended Citation}

Leeson, Joseph (2019) "A Georgist Perspective of Petroleum Taxation," Indiana Journal of Global Legal Studies: Vol. 26 : Iss. 2 , Article 8.

Available at: https://www.repository.law.indiana.edu/ijgls/vol26/iss2/8

This Note is brought to you for free and open access by the Law School Journals at Digital Repository @ Maurer Law. It has been accepted for inclusion in Indiana Journal of Global Legal Studies by an authorized editor of Digital Repository @ Maurer Law. For more information, please contactrvaughan@indiana.edu.

\section{$\Psi$}

JEROME HALL LAW LIBRARY

INDIANA UNIVERSITY

Maurer School of Law
Bloomington 


\title{
A Georgist Perspective of Petroleum Taxation
}

\author{
JOSEPH LEESON
}

What is this you call property? It cannot be the earth, for the land is our mother, nourishing all her children, beasts, birds, fish and all men. The woods, the streams, everything on it belongs to everybody and is for the use of all. How can one man say it belongs only to him?

\section{$\sim$ Massasoit}

Over a century ago, the town of Arden, Delaware, was founded on a unique single-tax-community system that radically altered the popular concept of land ownership. ${ }^{1}$ This system was premised on concepts developed by a man few know today but who was a major figure in economics during the 1800s, Henry George. ${ }^{2}$ George's public finance theory has been described as having received "intermittent attention over the years, with many eminent names in economics making at least a passing comment, but it has seen comparably little action in the policy debate arena and has been largely ignored by the modern era of academic economics." 3 Although George's original plans for a single-tax system have failed to gain momentum in economic and tax policy circles, his single-tax-system philosophy is exemplified in twenty-first century natural resource taxation (most prominently in the taxation of oil). An application of the economic and procedural rationales that underpin George's single-tax system indicates that petroleum taxation should be based on a severance tax system that promotes the efficient distribution 2017).

1. See Village of Arden, Delaware, http://arden.delaware.gov/ (last visited Nov. 19,

2. See id.; See Fred Foldvary, Public Goods and Private Communities 134-151 (1994).

3. Zachary Gochenour \& Bradley Caplan, An Entrepreneurial Critique of Georgism, 26 Rev. Austrian Econ. 483, 485 (2013); see also Mark Blaug, Book Review to RoBERT V. ANDElson, CRITICS OF HENRY GEORGE. A CENTENARY APPRAISAl OF THEIR STRICTURES ON ProgReSS AND POVERTY, 47 ECONOMICA 471, 472 (1980) ("As Milton Friedman said in a public debate in 1978, 'In my opinion the least bad tax is the property tax on the unimproved value of land, the Henry George argument of many, many years ago"').

Indiana Journal of Global Legal Studies Vol. $26 \# 2$ (Spring 2019)

(C) Indiana University Maurer School of Law 
of common property benefits to the public. The outcome of such a system is the creation of a property rights institution that combines interests shared by libertarians (greater emphasis on individual rights through private ownership and less distortionary impacts on economic transactions), greens (greater incentives to preserve natural resources), and socialists (redistributing benefits attributable to property rights).

\section{GeNERAL OvERVIEW}

The concept of property ownership has been contemplated and discussed over time between many of the most prominent philosophers. Plato originally supported collective ownership as a necessary method to promote the pursuit of common interest and to avoid social divisiveness. 4 Plato later retreated from this idealism in favor of Aristotle's more practical concept of private ownership, which emphasizes prudence and accountability. In support of this theory, Aristotle argued that "when everyone has a distinct interest, men will not complain of one another, and they will make more progress, because everyone will be attending to his own business . . .."5 John Locke's labor theory of property expanded on Aristotle's private property theories by premising property rights on the exertion of labor upon natural resources. 6

Locke's labor theory of property does not extend to land ownership because historically it has been decided by first discovery or conquest, ${ }^{7}$ which originally did not conflict with Locke's philosophical musings because an unlimited supply can justify the taking of common land as private property, as historically land has been considered an overly abundant resource. ${ }^{8}$ In recent years, this concept has been criticized for

4. See Jeremy Waldron, Property and Ownership, in STANFORD ENCYCLOPEDIA OF Philosophy (Winter ed. 2016).

5. Id. at 4 .

6. See Karen I. Vaughn, John Locke and the Labor Theory of Value, 2 J. of Libertarian Stud. 311, 313 (Locke started from the Biblical premise that God gave the world to all mankind in common. Under what circumstance, Locke asked in his Second Treatise on Government, could one be justified in enclosing a piece of that common heritage and claiming exclusive ownership? "Though the Earth, and all inferior creatures be common to all men, yet every man has a property in his own person. This nobody has any right to but himself. The labor of his body, and the work of his hands, we may say, are properly his").

7. See generally Tonya Gonnella Frichner (Special Rapporteur on Indigenous Issues), Preliminary Study of the Impact on Indigenous Peoples of the International Legal Construct Known as the Doctrine of Discovery, U.N. Doc. E/C.19/2010/13 (Feb. 4, 2010); SHARON KORMAN, THE RIGHT OF CONQUEST (1996); see also Johnson v. Mintosh, 21 U.S. 543, 543 (1823); Oneida Indian Nation v. Cty. Of Oneida, 414 U.S. 661, 665-72 (1974).

8. See FOOD AND AGRICULTURE ORganIZATION OF THE UNITED NATIONS \& UNITED Nations Environment Programme, The FUture of OUR LAND (1999). See also Peter H. 
being draconian on indigenous cultures and infringing on human rights. ${ }^{9}$ On the other hand, natural resources, particularly oil, create a unique problem in the property rights realm because of their limited supply, natural origins, and the labor required to implement their usage. ${ }^{10}$

A number of seventeenth-century philosophers, such as Hobbes, Locke, and Grotius, reasoned that a property rights system that vests complete ownership with private entities infringes on the community's freedoms because common property derived from the earth was created for the enjoyment of humankind, not for the enjoyment of any particular person. ${ }^{11}$ When an unowned natural resource is appropriated, an enforceable right to exclude is created, and a freedom that others previously had is denied. ${ }^{12}$ Without unrestricted access to other resources of equivalent value or a redistribution of benefits to compensate for the loss of freedom, this appropriation of property rights creates an unequal distribution of freedom. ${ }^{13}$ The dilemma created by this equal freedom issue is the need for private property ownership as an incentive to stimulate economic activity while trying to balance the need to prevent the exclusivity of natural property benefits that theoretically belong to humanity as a whole. ${ }^{14}$ Due to population growth and the fixed nature of land and natural resources, this issue has

Lindert, Land Scarcity and American Growth, 34 J. ECON. HISTORY 851 (1974); Jens A. Andersson, The Politics of Land Scarcity: Land Disputes in Save Communal Area, Zimbabwe, 25 J. S. AFR. STUD. 552, 553 (1999).

9. See generally Frichner, supra note 7 (Special Rapporteur on Indigenous Issues).

10. See Thomas Sikor et al., Property Rights Regimes and Natural Resources: A Conceptual Analysis Revisited, 93 WORLD DEv. 337, 337-49 (2017) (divides property rights of natural resources into eight categories and determines that there is a trend in the direction of compensated exclusions for natural resources); ROBERT L. HIRSCH ET AL., PEAKING of World OIL PROduction: ImpaCts, Mitigation, \& Risk Management 64 (Feb. 2005) ("Oil scarcity and several-fold oil price increases due to world oil production peaking could have dramatic impacts. The decade after the onset of world oil peaking may resemble the period after the 1973-74 oil embargo, and the economic loss to the United States could be measured on a trillion-dollar scale."); Herman Daly et al., Modernizing Henry George, Center fOR the AdVANCEMENT OF THE STEAdY STATE Economy (Jul. 18, 2010), http://www.steadystate.org/modernizing-henry-george/ (last visited Nov. 21, 2017).

11. Vaughn, supra note 6, at 311-12 (Locke's labor theory of property ownership premised ownership from natural resource exploitation had not been disputed because it involved a mixture of resources with labor making it property of the laborer.); See Chris Armstrong, Natural Resource Ownership, in INTERNATIONAL ENCYCLOPEDIA OF ETHICS 1-2 (Hugh LaFollete ed., 2017).

12. See Hillel Steiner, Left-Libertarianism and the Ownership of Natural Resources, BLEEDING HEART LIBERTARIANS (Apr. 24, 2012), http://bleedingheartlibertarians.com/ 2012/04/left-libertarianism-and-the-ownership-of-natural-resources/.

13. See id.

14. See Armstrong, supra note 11, at 2-4. 
become more pronounced and has directly contributed to a growth of inequality. ${ }^{15}$

Locke's labor philosophy of private ownership has played an important role in the implementation of real and natural property ownership, but there have been numerous proposals to enact a system that spreads the exclusive benefits associated with land and natural resources without implementing communal ownership. Many of the U.S. founding fathers joined Adam Smith in voicing concern with the concept of exclusive ownership over the Earth's benefits. ${ }^{16}$ In response to the congestion occurring in the North American colonies after the revolution, Thomas Paine was one of the first to propose a system that would impose an inheritance tax upon landowners for the right to prevent others from accessing the benefits of their property. ${ }^{17}$ Paine's theories on addressing the inequities of property ownership failed to garner support, but his social welfare ideas were later implemented in the form of an estate tax and universal social insurance system.18 Paine's proposed system of using taxation to remedy a social inequity became relevant again when Henry George advocated for the property tax in his single-tax proposition. ${ }^{19}$

Rather than trying to design a system that continuously redistributes common property and ignores the economic issues of socialism and communal ownership, George proposed to appropriate the value of land through a single tax on its unimproved value. ${ }^{20}$ Although the most promising economic aspect of single value taxation is the nondistortionary effect a property tax has on commerce, ${ }^{21}$ "George was not

15. See Tim Rayner, The Earth is Full: Scarcity and Abundance Thinking, PłسOSOPHY FOR CHANGE (July 31, 2013), https://philosophyforchange.wordpress.com/2013/07/31/theearth-is-full-scarcity-and-abundance-thinking/. See also Thorvaldur Gylfason \& Gylfi Zoega, Inequaility and Economic Growth: Do Natural Resources Matter? (Center for Economic Studies and Ifo Institute, Working Paper No. 712, 2002) (increased dependence on natural resources tends to go along with less rapid economic growth and greater inequality in the distribution of income across countries).

16. See Lexington, Estate Tax and the Founding Fathers: You Can't Take It With You, THE ECONOMIST (Oct. 24, 2010), https://www.economist.com/blogs/lexington/2010/10/estate tax_and_founding_fathers.

17. See Thomas Paine, Agrarian JUSTICe 10-17 (1797).

18. See ERIC Schliesser, Ten Neglected Classics of PHILOSOPHy 56-58 (2016).

19. See Brent Ranalli, After Paine: Henry George's "Single Tax", ThE Globaiıst (July 4, 2015), https://www.theglobalis t.com/after-paine-henry-george-single-tax/.

20. See Henry George, Progress AND Poverty 120-40 (1920).

21. See Joseph E. Stiglitz, The Theory of Local Public Goods, in THE Economics of PuBlic SERVICES, 274-333 (1974) ("Not only was Henry George correct that a tax on land is non-distortionary, but in an equilibrium society ... tax on land raises just enough revenue to finance the (optimally chosen) level of government expenditure."); Colin Read, The Henry George Theorem, in ThE PUBLIC FinANCIERS, 217-19 (2016). 
simply trying to design a system of taxation devoid of untoward commercial consequences"; he was trying to solve the ethical problem of inequity driven by land ownership, which can lead to its own economic problems and social unrest. ${ }^{22}$ "His goal was nothing less than to make all land common property, but he realized that, '[i]t is not necessary to confiscate land; it is only necessary to confiscate rent."' 23

George's theories were primarily concerned with the exclusivity of land ownership, but libertarians have found much of the same ethical reasoning to extend to all real property of limited supply. ${ }^{24}$ Despite the close relationship George's single-tax theories have with land, the Georgist tax system can be applied to numerous other types of activities, such as hoarding, pollution, and natural resource extraction. "Much like Pigovian taxes, the Georgist system is designed to levy taxes with the intent of deterring and punishing undesirable behavior but, unlike Pigovian's externality approach, the Georgist tax system places emphasis on the avoidance of taxing productive economic behaviors; like engaging in labor, and buying and selling goods." 25 Henry George's theories have served as a foundation for Geolibertarian taxation principles that extend the land ownership issues to all resources derived from common property, such as water, air, space, and oil, ${ }^{26}$ that are not eligible for private ownership. ${ }^{27}$ Therefore, society should tax those who own exclusive natural opportunities. ${ }^{28}$ The Georgist tax theories have also had a significant influence on tax policy development in the United

22. George, supra note 20, at 121 ("the fact that the land on which and from which all must live is made exclusive property of some. Like rip van winkle they lay down and sleep, not having done anything, but rather from the increase of the population, owners of land become millionaires. This creates a systemic problem of inequity because as common property such as land grows in value, workers are then required to pay more for the privilege to work on it").

23. Charles L. Hooper, Henry George, LIBRARY OF ECONOMICS AND LIBERTY, http://www.econlib.org/library/Enc /bios/George.html (last visited Nov. 19, 2017).

24. See Robert F. Conrad \& Malcolm Gillis, Progress and Poverty in Developing Countries: Rents and Resource Taxation, in HENRY GEORGE AND CONTEMPORARY ECONOMIC DEVELOPMENT 25 (Stephen R. Lewis ed.), http://www.cooperativeindividualism.org/gillis-malcolm_progress-and-poverty-in-developing-countries.pdf ("[Adam] Smith made a strong case for classifying natural resource deposits as "land". . . Harry Gunnison Brown, also considered natural resource deposits as essentially no different from unimproved agricultural land[").

25. Georgism, Capitalism, and Socialism, A GeORGIST Perspective, http://povertythinkagain.com/controversies/a-word-from-the-sponsor-of-the-film-the-endof-poverty-georgism-capitalism-and-socialism/ (last visited Nov. 19, 2017).

26. See Fred Foldvary, The Geolibertarian Ethics of Land Rent, BleEding HEART LIBERTARIANS (Apr. 25, 2012), http://bleedingheartlibertarians.com/2012/04/thegeolibertarian-ethics-of-land-rent/.

27. See GEORGE, supra note 20 , at 322-35.

28. See id. 
States. ${ }^{29}$ In most countries, particularly least developed countries, "rent capture has become a widely sought, perhaps paramount, goal of tax policy in natural resource sectors . ..."30

\section{SINGLE-TAX SYSTEM}

Henry George's single-tax system proposal was a simple solution to address the inequities associated with land as well as alleviate the strains associated with labor taxation. The proposal was to eliminate all taxes and impose a single tax on the undeveloped value of land. ${ }^{31}$ The single tax would be designed so that it levies a rent on land value while not applying any tax on productive activities, such as earnings or salaries. ${ }^{32}$ Theoretically, this proposal would be easy to administer, redistribute benefits exclusive to landowners, and allow individuals to retain the products of their labor. ${ }^{33}$ Furthermore, it would help to fix the injustices associated with tax burdens being placed on the working man and reduce incentives for land speculation. ${ }^{34}$ The ultimate goal of the tax was to shift the land ownership from exclusive, individual ownership to one of communal, beneficial ownership. ${ }^{35}$

Many of the advocates for a Georgist taxation system on undeveloped common property hold that it is distinguishable from exchange taxes because it does not bear on production. ${ }^{36}$ Henry George most prominently stressed that "land value does not express a reward of production" but rather "expresses the exchange value of a monopoly;";

29. See Alanna Hartzok, In the History of Thought: Henry George's "Single Tax," EARTH RIGHTS INSTITUTE, http://www.earthrightsinstitute.org/news/publications/essaysreports-etc/240-in-the-history-of-thought-henry-george-s-single-tax (Dec. 2, 2018), ("The 1887 Wright Act in California enabled bonds raised by local irrigation districts to be paid from the increase in land values [ . . . ]" United States' taxpayers currently subsidize the irrigation needs of agribusiness through tax credits, quotas and redistribution of tax revenue ... Alaska's state constitution vests the ownership of oil and other natural resources in the people as a whole and the state's Permanent Fund distributes substantial oil revenue as citizen dividends to state residents.). See also Land Reform, THE REMEDY, http://www.henrygeorge.org/rem2.htm (last visited Nov. 19, 2017) ("In the United States, the largest landholding entities, in terms of area, are oil and timber companies, holding many millions of acres").

30. Conrad \& Gillis, supra, note 24, at 26.

31. See GEORGE, supra note 20, at 132-39.

32. See id.

33. See id.

34. See id.

35. See Bob DeNigris, Henry George and the Single Tax, ThE ARDEn GeORgiST GIID (Oct. 2007), http://www.henrygeorge.org/pdfs/denigris.pdf.

36. See E.S.L., Why Henry George Had a Point, The Economist (Apr. 2, 2015), https://www.economist.com/free-exchange/2015/04/01/why-henry-george-had-a-point. 
therefore, a "tax upon the value of land is the best tax that can be imposed ...." "37 "It is the most easily collected, does not allow cost shifting to third parties like corporate taxes do with consumers, the tax on land value possesses in the highest degree the element of certainty and due to the immovable, unconcealable character of the land itself it is beneficial for taxing enforcement purposes." 38

The theoretical element of George's tax system that tax is nondistortionary has drawn a significant amount of interest from economists. 39 "George's central economic argument [for the single value tax system] is that the supply of land and natural resources are perfectly inelastic, therefore there is no efficiency loss from land value taxation." 40 A land value tax removes the land value subsidy, and most importantly, it does not interfere with consumption or production. "To minimize the need for distortionary taxes, economists have recommended maximizing rent taxes, which are supposed to be neutral." 41 Milton Friedman was a strong supporter of the property tax and argued that "the property tax is the least bad tax there is," prominently stating: "[T]hink of the original and indestructible properties of the soil. The least dangerous and harmful tax is a tax on something of which there is an inelastic supply." 42 On the other hand, critics argue that there is no way to determine the untransformed value of the land, even from one individual's subjective standpoint. ${ }^{43}$

Many rankings indicate that there is high residential satisfaction associated with taxation regimes influenced by the single-tax system. Alaska constitutionally vests natural resource ownership to the public and manages this interest through oil extraction and production taxes, which has helped it to be the only state where the wealth gap has decreased during the past decade. ${ }^{44}$ World Bank data indicates that

37. GEORGE, supra note 20 , at 134 .

38. Id.

39. See Gochenour \& Caplan, supra note 3, at 484-85 ("Fred Foldvary writes, 'Debates on tax reform, for example, focus on tapping streams of income or output, ignoring the possibility and advantage of using rents unrelated to human effort, thus eliminating disincentives, tax wedges, and excess burdens[.]"').

40. Id. at 484 .

41. Diderik Lund, Rent Taxation for Nonrenewable Resources 2 (Univ. Oslo Dep't of Econ., Working Paper No. 01, 2009), http://hdl.handle.net/10419/47338.

42. Brian Leubitz, Prop 13: What Would Milton Friedman Do?, CALIFornIa Progress REPORT (Aug. 9, 2009), http://californiaprogressreport.com/site/prop-13-what-wouldmilton-friedman-do.

43. See David J. Heinrich, Murray Rothbard and Henry George, MiSES InSTITUTE (Feb. 23, 2004), https://mises.org/blog/murray-rothbard-and-henry-george.

44. See Scott Santens, Is the Solution to Extreme Wealth Inequality Really - Alaska?, WORLD ECONOMIC FORUM (Apr. 26, 2017), https://www.weforum.org/agenda/2017/04/ extreme-wealth-inequality-alaska-model/. 
there is a direct correlation between land rent in the form of property taxes and freedom. In the Heritage Foundation's freedom index, Singapore, a country that imposes a higher property tax than most of the world and pays its citizens a dividend similar to Alaska, is at the top of the list. ${ }^{45}$ Similarly, Hong Kong has topped the index and is a city consisting completely of public land that collects enough rent to keep income taxes low. 46

In oil rich countries, the establishing methods to retain and redistribute the natural resource benefits within the country has helped to alleviate poverty. When Middle Eastern OPEC countries are compared to other countries with identical poverty levels during OPEC's growth and establishment, "OPEC countries have shown roughly double the reduction of people below the absolute poverty line." 47 Not only has establishing an OPEC redistribution helped to alleviate poverty levels, "middle eastern OPEC countries have experienced considerable reductions in resource inequality since 1975." 48 Furthermore, as a result of the increased revenues from a nationalized oil system, Middle Eastern countries have been able to invest more in socially productive sectors, such as education and military development. ${ }^{49}$

\section{An Overview of Petroleum Tax Systems}

There is no tax structure in the world that has been more impacted by Georgist ideals than the tax and redistributive systems of the oil and gas industry. The "IMF (2012) identifies 22 countries where petroleum revenues comprise at least 10 percent of national GDP, a fraction that rises as high as 80 percent (Angola) or even 90 percent (Timor-Leste) in certain cases." 50 Oil taxation poses a unique issue because, unlike land, undeveloped oil reserves are relatively impossible to accurately quantify unless the land is drilled and the oil well is emptied.51 Geological

45. See Jeffery J. Smith, Learned Libertarians Lean Toward Land Rents, ProgresS (Dec. 9, 2015), https://www.progress.org/articles/learned-libertarians-lean-toward-landdues.

46. Id.

47. Adam Bird \& Malcolm Brown, The History and Social Consequences of a Nationalized Oil Industry 15 (June 2, 2005) (unpublished paper) (on file with Stanford University).

48. Id. at 19.

49. See id. at 20-22.

50. James L. Smith, Issues in Extractive Resource Taxation: A Review of Research Methods and Models 3 (IMF Working Paper No. 12-287).

51. See Breffni O'Rourke, How Do Experts Estimate the Size of Oil and Gas Fields?, RADIOFREEEUROPE (Oct. 17, 2008, 9:49 GMT), https://www.rferl.org/a/How_Do_Experts _Estimate_The_Size_Of_Oil_And_Gas_Fields/1330630.html. 
experts can create estimates by examining seismic and aeromagnetic data for similarities with other oil wells, but this data is a scientific guess at best. $52 \mathrm{~A}$ proven reserve has a 90 percent probability of being accurately quantified, but these reserves need to be producing to achieve this accuracy. ${ }^{53}$ Due to experts' inability to measure and quantify oil amounts prior to extraction, it is administratively impossible to tax petroleum while it is underground. It would thus be unrealistic to apply George's single-tax system on the undeveloped value of oil reserves. As a result, governments throughout the world have applied Georgian systems that redistribute petroleum (a nonrenewable resource) benefits by implementing tax instruments that apply to the profits and volume of extracted petroleum.

In determining an effective tax system, George listed certain factors required for an effective tax: (1) it bears lightly upon production, (2) it is easily and cheaply collected and falls directly upon the ultimate payers, (3) it provides the least opportunity for tyranny or corruption by officials and the least temptation for lawbreaking and evasion by taxpayers, and (4) it bears equally as to give no citizen an advantage or disadvantage..$^{54}$ Most countries collect the government's share of economic benefit through production or income-based taxation. ${ }^{55}$ Other less popular taxation methods include value-added taxes, customs duties, and various rental payments. ${ }^{56}$ The three most prevalent means through which countries establish and implement redistributive oil tax systems are royalties, income taxes, and resource rent taxes. ${ }^{57}$

\section{Royalties}

Originally, the favored method of oil taxation was through royalty arrangements. ${ }^{58}$ Royalties have been attractive due to the administrative advantage of mandatory payments based on volume or value. 59 Royalties typically come in some form of severance or ad valorem tax, but some countries have introduced an earnings component by affiliating the tax with production levels (Chile, Ecuador, Norway,

52. See id.

53. See id.

54. See GEORGE, supra note 20 , at 132.

55. See Emil M. Sunley, Thomas Baunsgaard \& Dominique Simard, Revenue from the Oil and Gas Sector: Issues and Country Experience 10-13 (June 8, 2002) (unpublished post-conference draft), http://siteresources.worldbank.org/INTTPA/Resources/SunleyPaper .pdf.

56. See id. at 2.

57. See id.

58. See id. at 22-25.

59. See id. at 2-3. 
and Thailand) or nominal return (Peru and Kazakhstan). ${ }^{60}$ Due to royalty calculations being associated with value or volume, they are less administratively complicated to enforce than income-based taxes. On the other hand, companies disfavor this approach because, if it is not profit-based, it does not allow for cost reduction and can cause struggling oil companies to be forced out of business. Although royalties are still a popular tax scheme implemented by oil producing countries, governments have begun to emphasize tax systems that are more closely related to corporate revenue and income so that countries may be able to share in the increased profits that result from higher oil prices. ${ }^{61}$

\section{Income-based Taxes}

"In the last 60 years, the balance has shifted away from royalties toward the use of levies based on net income: although producing countries typically use both royalties and income-taxes, income-based taxes have gained over the decades in relative importance."62 Government reliance on income-based oil taxes tend to aggravate administrative issues because the revenue reductions that result from noncompliance appear to outweigh any of the incremental benefits associated with income-based taxes. ${ }^{63}$ "This is especially the case where royalties are 'progressive,' the rates of which vary positively with market prices."64 Although administratively difficult, countries have trended toward progressive production-sharing agreements and net income systems as a result of the positive fluctuations in oil prices. ${ }^{65}$

Taxes imposed on oil companies' profits and revenues fall away from

60. See id.

61. See Bryan C. Land, Resource Rent Taxation-Theory and Experience 3 (Sept. 22, 2008) (IMF Working Paper), https://www.imf.org/external/np/seminars/eng/ 2008/taxnatural/pdf/land.pdf ("The reason for this, at least in part, is the predominance of regressive fiscal regimes designed in the 1980s and 1990s. Common features of these fiscal regimes had included low royalties and flat rate income taxation combined with generous allowances (accelerated depreciation and investment uplifts). In the mining industry, many governments had also offered tax holidays in the depths of depression in the sector, backed by stabilization agreements. In the oil industry, the prevalence of volume rather than profit-based production sharing, coupled with generous cost recovery provisions to lure investors, entailed limited government sharing in any price escalation").

62. Michael C. Durst, Improving Natural Resource Taxation in Developing Countries, NAT. RESOURCE GOVERNANCE INST. (Jan. 5, 2017), https://resourcegovernance.org/blog/ improving-natural-resource-taxation-developing-countries.

63. See id.

64. Id.

65. See Petter Osmundsen \& Kjell Lovas, Thends and Trade-offs in Petroleum Tax Design, (USAEE, Working Paper No. 09-024, 2009), http://ssrn.com/abstract=1517149. 
the administrative benefits associated with applying taxes on undeveloped common property due to the inherent administrative difficulties in measuring net income. These difficulties leave them more prone to taxpayer avoidance through techniques such as base erosion and profit shifting. 66 Simpler taxes, such as royalties, are calculated based on the gross value of the extracted resource while income taxes are derived from net profits, which are always smaller than gross revenues.67 "Therefore, if an extractive company succeeds in understating the fair market value of its extracted product by even a small percentage, the government's revenue losses under a royalty might be negligible, whereas the government's revenue losses under an income-based tax are likely to be much more serious." Critics of incomebased oil taxes argue that governments have not been able to design profit calculations that overcome these vulnerabilities. ${ }^{68}$

Income-based taxes on petroleum can also lead to an overdependence on petroleum tax revenues, which has occurred in Norway where over 32 percent of Norway's total revenues come from taxes, excise duties, and other revenues from petroleum activities. ${ }^{69}$ "On top of its 27 percent corporation income tax, Norway levies an additional 51 percent resource extraction tax on the exploration, development, and production of petroleum."70 This poses a unique problem in Norway since petroleum exports have declined over the past decade. ${ }^{71}$

On the other hand, it is not unusual for oil rich countries in the Middle East to have low or no income taxes on corporations but apply an income tax solely on the oil industry. ${ }^{72}$ For example, "[i]n Bahrain, there are no corporate taxes with the exception of companies undertaking extraction and refining activities ... [who] are subject to tax at the rate of 46 [percent]." 73 Petroleum production and refining accounts for 20 percent of Bahrain's gross domestic product, 70 percent of Bahrain's

66. See Michael C. Durst, Improving the Performance of Natural Resource Taxation in Developing Countries, 9-12 (ICTD, Working Paper 60, 2016), http://www.ictd.ac/ publication/improving-the-performance-of-natural-resource-taxation-in-developingcountries/.

67. See id. at 9.

68. See Durst, supra note 62.

69. See Adam Michel, Norway's Addiction to Taxes on Oil, TAX Found. (June 9, 2014), https://taxfoundation.org /norway-s-addiction-taxes-oil/.

70. Id.

71. See id.

72. See generally PricewaterhouseCoopers, OIL AND GaS TAX Guide for the MIDDLE EAST 2015 (2015), https://www.pwc.com/gx/en /services/tax/publications/middleeast-oil-gas-guide.html (assessing country-specific developments of oil and gas fiscal and regulatory schemes in the Middle East).

73. Id. at 5 . 
export receipts, and over 80 percent of government revenues. ${ }^{74}$

\section{Resource Rent Tax}

The most unique and interesting petroleum taxation strategy arising in recent years is the resource rent tax (RRT). Royalty tax regimes can distort economic decisions because, without cost deductions, they make certain high-cost extraction projects unprofitable that would otherwise be profitable without the tax expenses. ${ }^{75}$ Australia and Papua New Guinea have responded to this discrepancy by creating the Resource Rent tax which "is imposed only if the accumulated cash flow from the project is positive ... and the net negative cash flow (in the early years of a project) is accumulated at an interest rate that, in theory, is equal to the company's opportunity cost of capital (adjusted for risk)." "76 "[T] while leaving to the investor at least the minimum required return on investment." 77 The RRT allows for a deduction equal in present value to the investment itself, and the deduction typically exceeds most depreciation reductions allowed under corporate income tax systems. ${ }^{78}$ Investment-indeed any yearly negative net cash flow-is carried forward for later deduction, along with interest accumulation, as soon as revenues allow. ${ }^{79}$

When Australia's tax review commission proposed that royalties be replaced with a uniform resource rent tax, it argued that "a welldesigned rent-based resource tax is less likely to distort investment and production decisions." 80 Properly designed, an RRT captures a share of the natural resource rent, which is the return over and above the company's opportunity cost of capital. ${ }^{81}$ If the tax base in subsequent years is sufficient to allow complete, effective deduction of the carryforward, this tax base can ensure that only the rent is taxed. 82 "But it is far easier to state this objective than it is to design taxes that can do

74. See id.

75. See Lund, supra note 41, at 5.

76. See INT'L MONETARY FUND, FISCAL POLICY FORMULATION AND IMPLEMENTATION IN Oil-Producing Countries 159 (Jeffrey M. Davis, Annalisa Fedelino \& Rolando Ossowski eds., 2003).

77. Land, supra note 61 , at 7.

78. See id. at 14.

79. See id.

80. John Freebairn, Royalties or Resource Rent Taxes?, TAX \& TRANSFER POL. InST. (Dec. 10, 2015), http://www.austaxpolicy.com/which-is-more-efficient-and-effectivecomparing-royalty-and-resource-rent-taxes/.

81. See id.

82. See id. 
this."83 The World Bank has highlighted two significant hurdles in implementing an effective resource rent tax: (1) designing an RRT system that is efficient at extracting rents when the existence and size of the resource is uncertain and (2) implementing the system with government informational and practical limitations. 84

Unfortunately, the RRT in practice also poses several issues regarding its implementation. The unpredictability and volatility of commodity prices makes the stable revenue stream of royalty taxes more desirable than resource rent taxes. ${ }^{85}$ On the other hand, resource rent tax regimes benefit private companies because the effective tax rate accounts for market fluctuations, thereby allowing for more stability for industry revenues. ${ }^{86}$ "In practice, [the resource rent tax] has always been imposed together with other taxes to offset these disadvantages." 87 "Thus, typically in a royalty/tax regime RRT is combined with royalty and corporation tax, either as a final tax or as supplementary levy on pre-tax income, payments of which would be deductible for corporation tax purposes." 88 The result of such a combination is the ability for governments to receive a steady stream of royalty tax revenue while simultaneously capturing excess benefits from commodity price spikes through the operation of the RRT. 89

\section{NATIONALIZATION OF Oח SUPPLIES}

"George viewed the institution of private property in land as the 'curse and menace of modern civilization,' for which the remedy was the conversion of all land to common property." 90 George advocated for a tax system to address this issue, but there has been a trend amongst oil-rich countries to legitimize the public's right to natural resources through

83. Land, supra note 61 , at 7.

84. See Arvind Virmani, Efficiency of Practical Resource Rent Tax Systems: Threshold Rates and Income Taxes 1 (World Bank Discussion Paper, No. DRD164, 1986), http://documents.worldbank.org/curated/en/301531468327561218/Efficiency-of-practicalresource-rent-tax-system-threshold-rates-and-income-taxes.

85. Freebairn, supra note 80 , at 4 ("Given wide swings over time in commodity prices, a royalty generates a more stable stream of special taxation revenue than the resource rent tax.").

86. Id. ("mining industry revenues and profits are more stable under a resource rent tax regime.").

87. Land, supra note 61 , at 11.

88. The Taxation of Petroleum and Minerals: Principles, Problems and PRACTICE (Philip Daniel, Michael Keen \& Charles McPherson, eds. 2010).

89. Land, supra note 61 , at 11 . ("The effect is that the government receives some revenue before the project reaches the point at which RRT is imposed.").

90. Conrad \& Gillis, supra note 24 , at 29. 
governmental involvement in the supply and extraction of petroleum.91 Oil-producing countries implement this type of system by taking an equity interest in, or controlling access to, the petroleum supply through production-sharing arrangements or nationalizing the oil supply. ${ }^{92}$ Although this system manages to capture and redistribute benefits of natural resources, it forfeits the necessary benefits of private ownership emphasized in a Georgian tax system.

In the Middle East, the majority of countries relies on some form of production sharing. ${ }^{93}$ Oil in Iraq is state-owned, and its extraction is controlled through technical service contracts awarded to international oil companies when the government seeks to expand production. ${ }^{94}$ Iraq also applies a corporate income tax at a low rate of 15 percent but foreign companies working in fields of oil and gas production, extraction, and related industries are all subject to a 35 percent tax rate of income earned in Iraq. ${ }^{95}$ In the United States, Article 8 of Alaska's state constitution nationalizes the oil supply by placing property interest in natural resources within a state public trust, which allows all citizens to have an ownership interest in the oil extracted from the state's lands. ${ }^{96}$ Article 9, Section 15 of the Alaska Constitution developed the Alaska permanent fund that facilitates this ownership interest by distributing profits to the state's citizens. ${ }^{97}$ Due to the unpredictable nature of resource extraction, establishing oil revenue funds has become popular among oil-producing countries which are believed to stabilize the economy and provide intergenerational redistribution of oil wealth. ${ }^{98}$

A tax system is preferable to nationalizing the oil supply because of the significant issues associated with the deprivatization of natural resources. When natural resources are privately owned, coordination and application of resources are determined by market incentives that direct resources to where they are highest valued.99 Furthermore,

91. See Associated Press, The Troubling Trend of Nationalization, NBC NEws (May 2, 2006, 6:33 PM), http://www.nbcnews.com/id/12600039/ns/business-oil_and_energy/t/ troubling-trend-nationalization/\#.WjbM2LpFyhc.

92. See Sunley, Baunsgaard \& Simard, supra note 55, at 10-13.

93. See J. William Carpenter, The Biggest Oil Producers in the Middle East, INVESTOPEDIA, https://www.investopedia.com/articles/investing/101515/biggest-oilproducers-middle-east.asp (last visited Oct. 15, 2015).

94. See Oil and Tax Guide for the Middle East, supra note 72, at 19-24.

95. See id.

96. See AllASKA CONST. art. VIII.

97. See id. at art. IX, § 15 .

98. See Dina Azhgaliyeva, The Effect of Fiscal Policy on Oil Revenue Fund: The Case of Kazakhstan, 5 J. Eurasian Stud. 157, 157-58 (2014).

99. See Richard Stroup \& John A. Baden, Property Rights and Natural Resource Management: A Bibliographical Essay by Stroup and Baden, ONLINE LIBR. OF LIBERTY 
privately-owned property rights preserve individual freedoms, encourage maximizing property value through ownership incentives, and allow free market powers to determine price levels based on the level of inputs and outputs of comparable products. 100 These essential benefits are either weakened or lost when the government takes complete control of common property like petroleum resources. ${ }^{101}$ Much like the nationalization trends in the Middle East, governmental involvement raises the inevitable possibility of "conflicts of interest arising from the government's role as regulator overseeing the environmental or social impact of a project, which may differ from its objectives as a shareholder."102 Corruption becomes most opportune when the government has a significant involvement with the contracting and business of oil extraction; therefore, equity arrangements are prone to corruption. ${ }^{103}$ This principle has been prominently exemplified in countries, such as Venezuela and Brazil, where public officials' corrupt practices have been involved with the nationalized oil business. ${ }^{104}$

(last modified Apr. 13, 2016), http://oll.libertyfund.org/pages/property-rights-and-naturalresource-management-a-bibliographical-essay-by-stroup-and-baden\#lev1sec01.

100. See D. Benjamin Barros, Property And Freedom, 4 N.Y.U. J. L. \& Liberty 36, 47 (2009); Sean Ross, How are Capitalism and Private Property Related?, INVESTOPEDIA, https://www.investopedia.com/ask/answers/040615/how-are-capitalism-and-private-

property-related.asp?lgl=myfinance-layout-no-ads (last visited Apr. 6, 2015); Jeremy Waldron, Property and Ownership, STAN. ENCYCLOPEDIA OF PHIL. (2004), https://plato.stanford.edu/archives/win2016/entries/property.

101. See Benjamin Barros, Property And Freedom, 4 N.Y.U. J. L. \& Liberty 36, 47 (2009); Sean Ross, How are capitalism and private property related?, INVESTOPEDIA (Apr. 6, 2015), https://www.investopedia.com/ask/answers/040615/how-are-capitalism-andprivate-property-related.asp?lgl=myfinance-layout-no-ads; Property and Ownership, STANFORD ENCYCLOPEDIA OF PHILOSOPHY (Edward N. Zalta ed., Winter 2016 Edition) https://plato.stanford.edu/archives/win2016/entries/property.

102. Sunley, et al., supra note 55, at 10.

103. See Munza Mushtaq, Corruption in state-owned enterprises is a global menace, INTL ANTI-CORRUPTION CONFERENCE (Dec. 3, 2016), https://iaccseries.org/ blog/corruption-in-state-owned-enterprises-is-a-global-menace/ ("State-owned enterprises are considered vital to many developed and developing countries; however, both corruption and bribery continue to plague many of them, despite welcome changes adopted by countries towards addressing these issues"). See generally Rabah Arezki \& Markus Brückner, Oil Rents, Corruption, and State Stability: Evidence From Panel Data Regressions (IMF, Working paper No. 09/267, Dec. 2009) (measuring state involvement and corruption in government dealings with oil agreements).

104. See Gustavo Coronel, The Corruption of Democracy in Venezuela, CATO (March 2008), https://www.cato.org/publications/commentary/corruption-democracy-venezuela (One of the main reasons for high levels of corruption in Venezuela has been "the record oil income obtained by the nation, money going directly into Chavez's pockets[.]”); Brazil Corruption Scandals: All You Need to Know, BBC NEWS (April 8, 2018) ("Since 2014 
Not only does nationalizing the oil supply create problems associated with deprivatizing property, the lack of success by stateowned petroleum enterprises indicates that governments are illequipped to manage the oil production and extraction business. Some state-owned enterprises (SOE) have produced substantial returns during periods of high mineral prices; however, there are many examples of countries where SOE's have failed to create anything other than operating losses. ${ }^{105}$ In Indonesia, the SOE, PERTAMINA, incurred over $\$ 10$ billion in debts due to operating losses between 1972 and 1976. ${ }^{106}$ During the same period, the Bolivian SOE, COMIBOL, failed to contribute any tax revenues to the treasury for a twenty-year stretch. ${ }^{107}$ "Brazil's Petrobras and Colombia's Ecopetrol experienced consistent operating losses in the late '70's." 108 "In 1981 and 1982, Argentina's state oil company incurred annual losses of over $\$ 3.7$ billion." 109 "These were the largest losses incurred by any company in the world in these years."110 "Other mineral SOE's, including Zambia Industrial and Mining, Brazais CVRD, and Zaire's Gecamines, have made only modest contributions to their national treasuries in recent years because of low mineral prices (copper) or other internal factors." 111

\section{Georglan Tax System of Petroleum}

The ability to correct the inequitable distribution of benefits from common property while retaining the benefits associated with private property rights is the primary factor behind implementing an effective Georgian system of tax collection. To implement such a system effectively, it must be administratively operational enough to maximize governmental revenues while also enforcing a property rights framework that reflects the communities' interest in natural resources. As a result, the best way to apply George's philosophies to the extraction and use of oil is a severance tax framework with a long-term fund to account for industry fluctuations.

Balancing the public's interests in natural resources with private interests has proven to be a complicated task for countries all around

\footnotetext{
Brazil has been gripped by a scandal that started with a state-owned oil company and grew to encapsulate people at the very top of business - and even presidents").

105. See Conrad \& Gillis, supra note 24 , at 27-29.

106. See id.

107. See id.

108. Id. at 28.

109. Id.

110. Id.

111. Id.
} 
the world. Most countries have structured their extraction rights systems to account for the public interest. In virtually all countries, with the exclusion of the United States, the public retains partial rights to natural resources by vesting extraction rights with the central government. ${ }^{112}$ These systems have led to burdensome licensing processes that distribute extraction rights through contractual arrangements with oil companies that seek exploration and extraction of oil underground.113 Alternatively, the United States' system avoids these inefficiencies by vesting to the surface land owner the extraction rights of underground resources. ${ }^{114}$ Therefore, the rights to common property ownership in the United States are completely vested in private entities or individuals. ${ }^{115}$

But how can an extraction rights system, like the American system, address the issues associated with communal ownership while vesting ownership with private entities? By enforcing a severance tax on extracted natural resources, taxes can separate communal rights from private ownership. Edella Schlager and Elinor Ostrom theorize that common property rights and the duties imposed on third parties through property rights are the products of applying the rules to natural resources. ${ }^{116}$ A Georgian tax system falls under Schlager and Ostrom's meaning of rules, which are defined as "generally agreed-upon and enforced prescriptions that require, forbid or permit specific actions . . . . To view the application of rules to "common-pool resources" from an ownership perspective, Schlager and Ostrom categorize rights into two classes: operational rights and collective rights. The first subgroup consists of the rights of "access and withdrawal," and the second subset encompasses "management, exclusion, and alienation." 117 Each of these categories of rights is dependent on the exercise of the others but are distinguishable from each other because they involve "the difference between exercising a right and participating in the definition of future rights to be exercised ...."118 To illustrate, a prospecting party must exercise the rights of accessing or withdrawing a resource (such as extracting underground oil) for it to exclude other parties from the

112. See Mineral rights ownership - what is it and why is it so unique in the USA?, INT'L ENERGY NETWORK (Last visited Dec. 2017), http://www.ieneurope.com /pdf/Mineral.pdf.

113. See id.

114. See id.

115. See id.

116. See Edella Schlager \& Elinor Ostrom, Property-Rights Regimes and Natural Resources, 68 LAND ECON. 249, 249-50 (1992).

117. Id. at 251.

118. Thomas Sikor et al., Property Rights Regimes and Natural Resources: A Conceptual Analysis Revisited, 93 WORLD DEv. 337, 337-38 (May 2017). 
newly acquired property. ${ }^{119}$

A severance tax regime is the only tax system that effectively corrects the inequity associated with petroleum because it views oil from the perspective of Schlager and Ostrom's two-order, property rights framework. The first set of rights reflects individual freedoms that each person has to remove a resource from its natural environment while the second set of rights signify that all people may take advantage of the benefits associated with scarce property derived from the earth. ${ }^{120}$ Although severance taxes are so named for being an excise tax "upon all persons, firms, corporations, or associations of persons engaged in the business of severing natural resources from the soil or water . . .,"121 severance taxes can also be viewed as a method of "severing" the public's vested rights in common property by compensating the community for excluding freedoms associated with ownership and usage of a limited natural resource. ${ }^{122}$ Because severance taxes are based on the value or quantity of oil extracted, a severance tax system is applied in a manner that prioritizes capturing benefits of collective rights rather than a share of oil companies' proceeds. Most importantly, such a system reserves the benefits of incentivizing productive activity through private ownership, retains the benefits of communal ownership, and avoids licensing burdens. ${ }^{123}$

Severance taxes are a favorable form of oil tax because they are the most practicable tax system in terms of administrative efficiency. "The literature on optimal taxation suggests that the government should raise revenue by using the tax instruments with the lowest efficiency costs."124 Australia's resource rent tax was proposed with the primary purpose to avoid distorting business decisions by only taxing profitable extraction operations. ${ }^{125}$ Similarly, some countries like Norway, have cost-recovery tax structures that allow an income reduction by a portion or all of the start-up costs, and companies who do not have a net

\section{See id.}

120. See id.

121. Act. No. 31, 1920 La. Acts 31 (levying a severance tax on people removing resources from the earth).

122. Jack Mintz \& Duanjie Chen, Capturing Economic Rents from Resources Through Royalties And Taxes, 5 SRP RESEARCH PAPERS 1, 1-3 (Oct. 2012).

123. See Daniel Raimi \& Richard G. Newell, How The States Manage Revenue from Growing Oil and Natural Gas Production, SchOlars Strategy NeTwORK (Jan. 1, 2017), https://scholars.org/brief/how-states-manage-revenue-growing-oil-and-natural-gasproduction ("[D]irecting large shares of oil and gas revenue to state general funds and operational expenditures can be risky for year-to-year budgets, primarily due to the volatile nature of oil and natural gas prices").

124. Carlos de Miguel \& Baltasar Manzano, Optimal Oil Taxation in a Small Open Economy, 9 REV. OF ECON. DYNAMTCS 438, 440 (2006).

125. See Osmundsen \& Lovas, supra note 65. 
positive tax position are allowed to carry the deductible start-up costs forward with interest until the firm has a positive tax position. ${ }^{26}$ Any benefits gained from these complicated tax schemes are lost due to the administrative complexities and informational burdens associated with multifaceted tax systems. ${ }^{127}$ Severance tax systems achieve the goal of maximizing revenue collection and reducing the negative economic effects of taxes by avoiding the administrative burdens associated with calculating oil companies' economic rent and income.

Although taxes with minimal administrative burdens have a greater distortionary effect on business decisions, these effects are minimized by the level of economic rent associated with oil profits. The severance tax system implemented by state and local governments of the United States only accounted for $\$ 17$ billion of tax revenue, which is only 1 percent of national, state, and local revenue. ${ }^{128}$ In general, results show that a severance tax reduction in the United States substantially reduces state tax revenue but yields little change in oil drilling and production activity. ${ }^{129}$ This is likely because mining activities tend to create a higher level of economic rent, which means that oil taxes tend not to deter productive activity if imposed at an appropriate rate. ${ }^{130} \mathrm{As}$ a result, oil severance taxes can avoid deterring oil extraction by being imposed to balance the goals of optimizing revenue collection with the risk of deterring business growth, rather than forsaking one priority for the other.

But perhaps the greatest arguments supporting a severance tax system on natural resources is the need for frugality through diminished consumption, rather than incentivizing consumption through efficiency. Prioritizing frugality generates efficiency as a secondary consequence and incentivizes redistributing benefits

\footnotetext{
126. See id.

127. See id.

128. See How Do State and Local Severance Taxes Work?, Tax POLICY CTR. URBAN InST. \& BROOKINGS INST. (last visited Dec. 2017), http://www.taxpolicycenter.org/briefingbook/how-do-state-and-local-severance-taxes-work.

129. See Mitch Kunce, Effectiveness of Severance Tax Incentives in the U.S. Oil Industry, 10 INT'L TAX AND PUB. FINANCE 565, 565 (2003).

130. See Daniel Raimi, Understanding Pennsylvania's Proposed Severance Tax, RESOURCES FOR THE FUTURE (Aug. 1, 2017), http://www.rff.org/blog/ 2017/understanding-pennsylvania-s-proposed-severance-tax ("These taxes are levied on the volume or value of production, and can be attractive to governments because mining activities such as oil and gas production often generate economic rents, defined as profits over and above the levels necessary to incentivize private-sector investment."); JEFFREY M. DAVIS, ET AL., FisCal Policy Formulation and IMPLEMENTATION IN OIL-ProduCing COUNTRIES (J.M. Davis et al. eds., 2003) ("The choice of tax rate [applied to the petroleum industry] reflects the typically higher economic rent in the petroleum sector").
} 
associated with scarce resources through a scarcity rent. ${ }^{131}$ Emphasizing frugality through taxation that redistributes natural resource benefits has the natural consequence of reducing production and resource extraction so that resources are only applied to their most optimal uses. ${ }^{132}$ This can successfully reconstruct economics to prioritize conservation over consumption. ${ }^{133}$ Unhindered population growth and the resulting increased consumption will lead to rising natural resource costs, which will make natural resource taxes increasingly relevant in future policy considerations. ${ }^{134}$ Arguably, tax and economic policy should be tailored to direct resource use at a scale which nature can sustain.

An oil revenue fund is a necessary part of a severance tax system to address the unpredictable fluctuations in revenue and its impact on a government's budgeting. Alaska's permanent fund is a primary example of a public tax fund, and North Dakota has a similar provision in its constitution that establishes a fund to share benefits over time, which requires capturing 30 percent of annual tax receipts to be reserved for long-term investment. ${ }^{135}$ Without strict enforcement of fiscal responsibility, the perfect oil taxation systems will seem irrelevant because of the "resource curse" of the volatility, exhaustibility, and uncertainty of resources. ${ }^{136}$ Regardless of the relatively consistent demand for energy-producing resources, the oil industry is susceptible to dramatic economic fluctuations that are the result of unpredictable supply variances. ${ }^{137}$ These fluctuations have been a large part of the reason that countries have shifted away from volume-based taxation in favor of tax systems that associate their revenue collection with

131. See Herman E. Daly, Ecological Economics and Sustainable Development 47 (2007).

132. See id.

133. See Sally-Ann Joseph, A global natural resource consumption tax, INT'L SOC'Y FOR ECOLOGICAL ECON. (2012), http://www.isecoeco.org/conferences/isee2012-versao3/pdf/ 823.pdf.

134. See David Funkhouser, Population, Consumption and the Future, COLUMBIA U.: EARTH INST. (Apr. 27, 2012), http://blogs.ei.columbia.edu/2012/04/27/populationconsumption-and-the-future/.

135. See Stephen C. Fehr \& Melissa Maynard, North Dakota saves for the future with today's oil riches, USA TODAY (Aug. 28, 2013), https://www.usatoday.com/story/ news/nation/2013/08/28/north-dakota-oil-money/2715203/.

136. Azhgaliyeva, supra note 98, at 157-58; Confronting Budget Deficits, 3 IMF ECONOMICS ISSUES 1 (1996) ("Government budget deficits (the excess of spending over revenue) in industrial countries have been growing as a percent of GDP for the past 20 years. Large deficits emerged after the oil crisis in the mid-1970s and widened dramatically after 1980, largely the result of government overspending rather than meager tax receipts").

137. See id. 
corporate profits because, although these taxes are administratively more difficult to implement, they allow for governments to partake in the booms and busts of the industry. ${ }^{138}$ To account for the ebbs and flows of the oil business, it is necessary for governments to establish funds that provide a monetary cushion for decreases in tax revenues that result from decreased oil extraction.

\section{CoNCLUSION}

Henry George once said "[t]here is danger in reckless change, but greater danger in blind conservatism." 139 The inequities associated with owning natural resources under the current property rights regimes require a dramatic shift in the way the public views petroleum taxation. Historically, petroleum tax systems have been designed to prioritize revenue collection, which is exemplified by the trends toward tax systems that raise greater and more consistent revenue streams. 140 Although this philosophy has merits regarding the need for public funds, the priorities behind tax systems premised on either taking an interest in, or sharing in the surplus profits of, the oil industry need to be balanced with administrative feasibility and the need for implementing an equitable common property system. A severance tax is the only administratively effective tax system that fulfills this objective by creating a system that supports and reinforces private property rights while accounting for the inequities associated with natural resources. Although petroleum natural resource taxation is predominant in the oil industry because of oil extraction's role in the world economy, these principles extend to all-natural resources of limited supply, such as rare earth elements, water, and wood. ${ }^{141}$ The petroleum industry is a perfect example of the way a Georgian tax system can be used to enforce communal interests in limited natural resources. Further analysis of the application of severance taxes to other natural resources warrants discussion and may help to change the modern view of distributing limited resources.

138. See Land, supra note 61 , at 2.

139. Henry George, Social Problems 18 (1883).

140. See Osmundsen \& Lovas, supra note 65; The Troubling Trend of Nationalization, supra note 91.

141. See Daly, et al., supra note 10. 
